\title{
Comparison of the Efficacy of Eleven Soil Termiticides on the Formosan Subterranean Termite (Coptotermes formosanus)
}

\author{
by
}

Izumi Fujimoto*, Akio Enoki, Shuji Itakura and Hiromi Tanaka

\section{ABSTRACT}

Using the tunneling test, the standard test method recommended by the JWPA (JWPS-TS-S), the minimum effective concentrations of 11 chemicals, known as major soil termiticides in Japan, were determined. Addition of the emulsifying agent, Tween 80 , to the low water solubility chemicals among the termiticides yielded a 2 - to 8 -fold increase in their termiticidal efficacies. In contrast, addition of Tween 80 to the high water solubility chemicals produced no such enhancement of their termiticidal efficacies.

In the confined test, in the case of the repellent-type chemicals of the 11 chemicals, all the test termites ( 10 workers and 2 soldiers) became intoxicated or paralyzed and moribund within one hour of exposure to the minimum concentration fulfilling the criteria of the JWPA standard test method. In the case of non-repellent type chemicals, all the workers became moribund within 2 hours of exposure to the minimum concentrations fulfilling the criteria of the standard test method; in contrast, it took $4-24$ hours before the soldier termites became moribund.

Key words: Coptotermes formosanus Shiraki, termiticide, JWPA standard test method, tunneling test, confined test

\section{INTRODUCTION}

Formosan subterranean termites are considered as one of the most destructive insect pests of wooden structures throughout the world, especially in areas with warm, humid climates (Kuriachan and Gold 1998). Control of subterranean termites has always been an important concern of homeowners and the pest control industry. For the past 60 years, termite control has mainly relied on termiticide treatments (Schokecht et al. 1994; Ibrahim et al. 2003). Chlordane had nearly monopolized the termiticide market of Japan

Faculty of Agriculture, Kinki University, Nara 631-8505, Japan

*Corresponding author; Email: felixfuji@mvf.biglobe.ne.jp 
until the first half of the 1980's. However, this chemical was designated as a special chemical substance owing to its characteristics of not being readily degradable and showing high bioaccumulation and chronic toxicity, and was actually banned by an act passed in 1986 on the examination of chemicals and regulation of manufacture. Organophosphates such as chlorpyrifos or phoxim began to be hastily employed as a substitute for chlordane, and were widely used. Termite damage recurred frequently within 5 years of the treatment in chlorpyrifos- or phoxim-treated houses, especially in areas of inhabitation of C. formosanus. The unusually short duration of the termiticidal performance of these chemicals became an issue of concern (Tsunoda et al. 1989). Further, many lawsuits for health reasons were filed by the inhabitants of chlorpyrifostreated houses, as well as by those of the neighboring houses. In an attempt to overcome these problems with chlorpyrifos and phoxim, the rates of disappearance of these chemicals under various conditions and the minimum treatment concentrations of the two termiticides required to fulfill the criteria ofJWPA Standard No.13 (1992) were investigated (Enoki et al. 1995). These experiments demonstrated that more than $70 \%$ of the chlorpyrifos or phoxim disappeared, mainly by evaporation, within a year from the soil underneath the floors of houses treated with chlorpyrifos or phoxim in Kyoto, Nara or Osaka. Also, the minimum treatment concentration of chlorpyrifos or phoxim required to fulfill the criteria of the JWPA standard was in the range of $0.05 \%$ to $0.1 \%$. In those days, the treatment concentration of chlorpyrifos or phoxim for soil treatment defined by the specification of each chemical was $1 \%$. Therefore, it is almost impossible to obtain protection against termite attacks for 5 years of wood-constructions built on ground soil treated with $1 \%$ solutions of chlorpyrifos or phoxim, because of the rapid evaporation of these chemicals from the soil. Thus, measurements of the decay rate of a termiticide at the treatment site and the minimum treatment concentrations of the chemicals for complete prevention of termite attacks are essential for the proper use of termiticides, that is, use of optimal concentrations that would provide adequate protection against termite damage, while not posing a threat to the environment or to the health of living beings.

Recently, numerous types of termiticidal formulations, consistingofa variety of chemicals, have been developed as substitutes for organophosphates, and are already available commercially. It has been established that examination 
of the boring activity of subterranean termites in treated soil is essential for evaluation of the termiticidal efficacy of a soil treatment chemical (Tamashiro et al.1987; Su et al.1997). In this study, to determine the minimum treatment concentrations of 11 chemicals which are widely used as soil termiticides in Japan fulfilling the criteria of the JWPS-TS-S, the termiticidal efficacies of the major chemicals were evaluated by laboratory tests.

\section{MATERIALS AND METHODS}

\section{Test termites}

The subterranean termites, Coptotermes formasanus shiraki, were used for the laboratory experiments. All the termites were collected from a laboratory colony maintained at the Department of Applied biological chemistry, faculty of Agriculture, Kinki University.

\section{Test chemicals}

All the chemicals tested were of technical grade: permethrin, bifenthrin, etofenprox, silafluofen, dinotefuran, clothianidin, imidacloprid, thiamethoxam, fipronil, chlorfenapyr and chlorantraniliprole.

\section{Preparation of test samples}

A certain weight $(\mathrm{mg})$ of the chemical was dissolved in ethanol to obtain a given volume (undiluted solution). The solution was diluted with ethanol to the prescribed concentrations (diluted solutions). A certain weight (mg) of Tween 80 (Tokyo Chemical Industry co., ltd. GR) was dissolved in a given volume $(\mathrm{ml})$ of the undiluted solution; this solution was diluted to 50 times with distilled water to obtain an emulsion.

\section{Tunneling test}

The tunneling test was carried out in accordance with the JWPS-TS-S. Sandy loam sieved through 20 meshes was heat-sterilized at $60^{\circ} \mathrm{C}$ until its weight became constant, to obtain the non-chemically treated dried soil. Twelve $\mathrm{g}$ of the dried soil was placed in a grass beaker $(100 \mathrm{ml}, 5 \mathrm{~mm}$ inside diameter). Three $\mathrm{ml}$ of the dilute solution of a chemical or emulsion of the chemical was added to the dried sandy loam in the glass beaker and mixed thoroughly. The glass beaker was allowed to stand in a thermostat at $40^{\circ} \mathrm{C}$ for 28 days. Three $\mathrm{ml}$ of distilled water was added to the soil in the beaker every 7 days. After 28 days, the beaker was taken out from the thermostat 
and three $\mathrm{ml}$ of distilled water was added to the treated soil in the beaker. The moistened soil was tightly stuffed in to the transparent part of a glass tube ( $15 \mathrm{~mm}$ inside diameter; $5 \mathrm{~cm}$ length of the transparent zone) with both the ends made of frosted glass for sliding contact. The glass tube was connected to two glass cylinders at both ends. Wood flakes (Ca. $5 \mathrm{~g}$ ) were put into one of the two cylinders. Untreated soil (Ca.20\% moisture content) was placed in another cylinder, as shown in Fig. 1. One hundred worker and 10 soldier termites were introduced into the untreated soil in the cylinder. The assembled unit was incubated at $28^{\circ} \mathrm{C}$ in the dark for 3 weeks. After this test period, the boring distance (gallery) by the termites was measured and the degree of boring caused by the pests was rated on the following scale.

Degree of boring

0 : No boring

1: Boring distance under $1 \mathrm{~cm}$

2: Boring distance under $2 \mathrm{~cm}$

3: Boring distance under $3 \mathrm{~cm}$

4: Boring distance under $4 \mathrm{~cm}$

5: Boring distance over $4 \mathrm{~cm}$

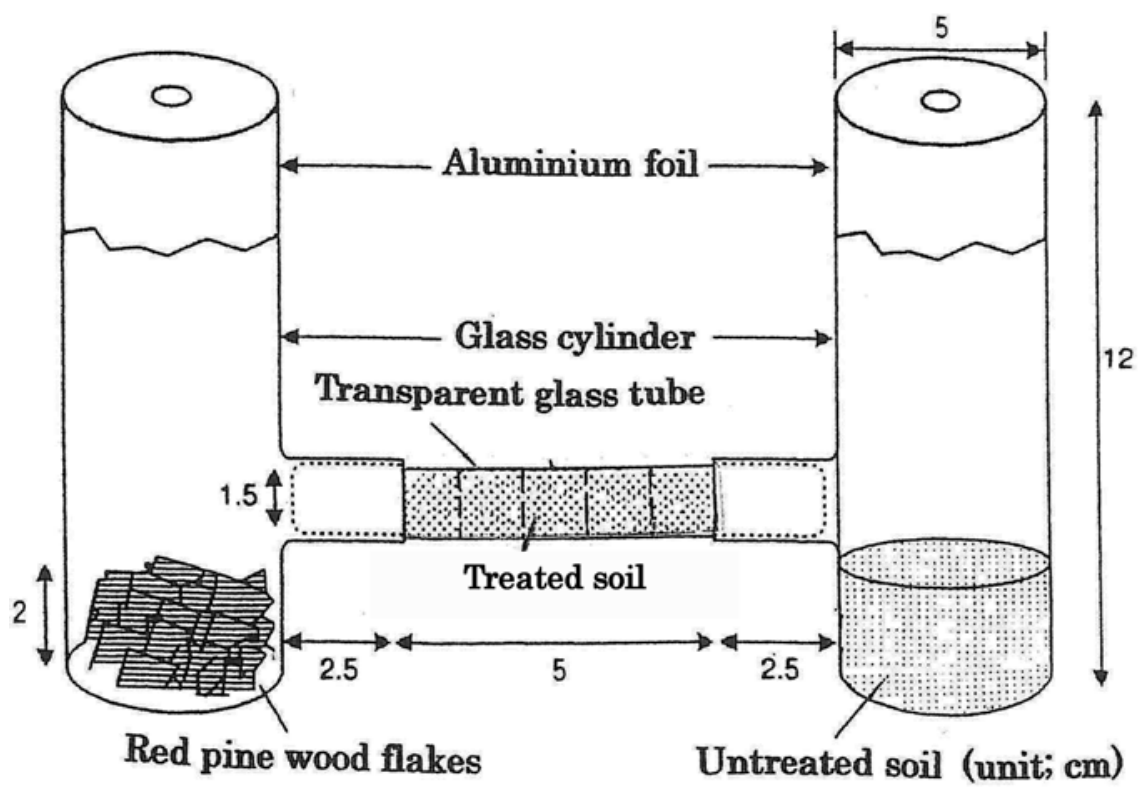

Fig.1. Apparatus for tunneling test. 
If all the test termites were dead before the end of the test period, the time elapsed (in days) was recorded. In order for the test chemicals fulfilling the criteria of the JWPS-TS-S, the degree of boring on the scale described above needs to be ranked 0 or 1 . However, the test chemical is still considered to fulfill the criteria of the standard when the ranking of the degree of boring on the scale is 2 , but all the test termites are dead within a week. Five replicates were prepared for each sample.

\section{Confined test}

Twenty g of dried sandy loam was placed in a glass beaker $(100 \mathrm{ml} ; 52$ $\mathrm{mm}$ inside diameter). Five $\mathrm{ml}$ of the dilute solution of a chemical or emulsion of the chemical was added to the soil in the beaker and mixed thoroughly. The beaker was allowed to stand in a thermostat at $40^{\circ} \mathrm{C}$ for 28 days. Five $\mathrm{ml}$ of distilled water was added to the soil in the beaker every 7 days. After 28 days, the beaker was taken out from the thermostat. Distilled water was added to the treated soil in the beaker to obtain a moisture content of $c a$. $23 \%$. The surface of the soil in the beaker was pressed and leveled off with the disk-shaped end $(1.5 \mathrm{~cm}$ diameter $)$ of a glass rod. Ten worker and two soldier termites were introduced into the soil in the beaker, as shown Fig. 2. The beaker was maintained at $28^{\circ} \mathrm{C}$ in the dark. The change in the activity of the termites was visually assessed every one hour for the first eight hours, and then every 24 hours. The times required for a $100 \%$ moribund rate (no ambulation) and $100 \%$ dead rate (no movement at all) of the termites were assessed. Three replicates were prepared for each sample.

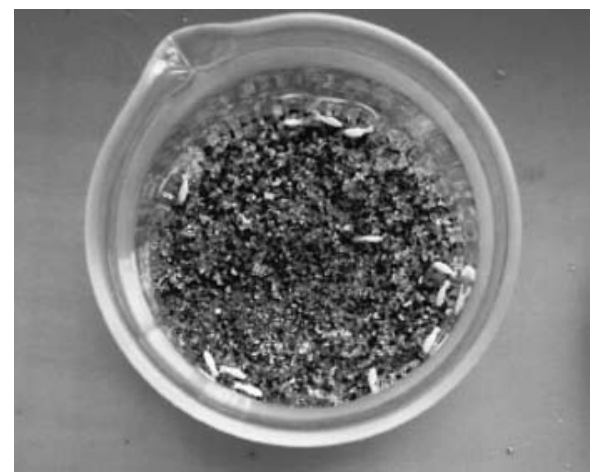

Fig.2. Apparatus for confined test.

\section{RESULTS AND DISCUSSION}

\section{Tunneling test}

The average distances and the average degrees of boring in the tunneling test of the 11 chemicals are shown in Table $1-3$. Termites penetrated the 
Table 1. Termiticidal efficacy of 4 pyrethroids, permethrin, bifenthrin, etofenprox, and silafluofen, in the tunneling test (JWPS-TS-S).

\begin{tabular}{|c|c|c|c|c|}
\hline Chemicals & $\begin{array}{l}\text { Conc. } \\
\text { in soil (ppm) }\end{array}$ & $\begin{array}{l}\text { Mean boring } \\
\text { distance } \\
(\mathrm{mm})\end{array}$ & $\begin{array}{l}\text { Mean } \\
\text { boring } \\
\text { degree } \\
\end{array}$ & Notes \\
\hline \multirow{3}{*}{$\begin{array}{l}\text { Permethrin } \\
+ \text { Tween } 80\end{array}$} & $25+0$ & 27 & 3 & All the termites were dead within 17 days \\
\hline & $50+0$ & 4 & 1 & All the termites were dead within 11 days \\
\hline & $25+125$ & 3 & 1 & All the termites were dead within 11 days \\
\hline \multirow{3}{*}{$\begin{array}{l}\text { Bifenthrin } \\
+ \text { Tween } 80\end{array}$} & $6.25+0$ & 16 & 2 & All the termites were dead within 11 days \\
\hline & $12.5+0$ & 3 & 1 & All the termites were dead within 11 days \\
\hline & $6.25+62.5$ & 1 & 1 & All the termites were dead within 11 days \\
\hline \multirow{3}{*}{$\begin{array}{l}\text { Etofenprox } \\
+ \text { Tween } 80\end{array}$} & $100+0$ & 23 & 3 & All the termites were dead within 12 days \\
\hline & $200+0$ & 5 & 1 & All the termites were dead within 12 days \\
\hline & $100+500$ & 1 & 1 & All the termites were dead within 11 days \\
\hline \multirow{4}{*}{$\begin{array}{l}\text { Silafluofen } \\
+ \text { Tween } 80\end{array}$} & $200+0$ & 15 & 2 & All the termites were dead within 11 days \\
\hline & $375+0$ & 9 & 1 & All the termites were dead within 11 days \\
\hline & $200+1,000$ & 4 & 1 & All the termites were dead within 12 days \\
\hline & $375+125$ & 9 & 1 & All the termites were dead within 11 days \\
\hline Tween 80 & 1,250 & 50 & 5 & Termites reached the wood flakes within 5 to 6 hours \\
\hline Untreated & - & 50 & 5 & Termites reached the wood flakes within 5 to 6 hours \\
\hline
\end{tabular}

untreated soil in the glass tube and reached the wood flakes in the opposite cylinder within 5 to 6 hours (Table 1 ). The termites also penetrated the soil layer containing 1,250 ppm (treated conc.; 5,000 ppm) of Tween 80 (w/w) and reached the wood flakes within 5 to 6 hours. The minimum effective concentrations in the soil of pyrethroids, permethrin, bifenthrin, etofenprox and silafluofen required to fulfill the criteria of the JWPS-TS-S were $50 \mathrm{ppm}$ (treatment conc.; 200 ppm), 12.5 ppm (50 ppm), 200 ppm (800 ppm) and $375 \mathrm{ppm}(1,500 \mathrm{ppm})$, respectively (Table 1$)$. When Tween 80 was added to each of the four pyrethroids at 5 to 10 times the amount of each pyrethroid, the minimum effective concentrations decreased to $25 \mathrm{ppm}$ (treatment conc.; $100 \mathrm{pm}$ ), $6.25 \mathrm{ppm}$ (25 ppm), $100 \mathrm{ppm}$ (400 ppm) and $200 \mathrm{ppm}$ (800 ppm), 
Table 2. Termiticidal efficacy of 4 neonicotinoids, dinotefuran, clothianidin, imidacloprid, and thiamethoxam, in the tunneling test. (JWPS-TS-S).

\begin{tabular}{|c|c|c|c|c|}
\hline Chemicals & $\begin{array}{l}\text { Conc. } \\
\text { in soil (ppm) }\end{array}$ & $\begin{array}{l}\text { Mean boring } \\
\text { distance } \\
(\mathrm{mm})\end{array}$ & $\begin{array}{l}\text { Mean } \\
\text { boring } \\
\text { degree (Avg.) }\end{array}$ & Notes \\
\hline \multirow{3}{*}{$\begin{array}{l}\text { Dinotefuran } \\
+ \text { Tween } 80\end{array}$} & $12.5+0$ & 33 & 4 & All the termites were dead within 4 days. \\
\hline & $25+0$ & 11 & 2 & All the termites were dead within 4 days. \\
\hline & $12.5+125$ & 31 & 4 & All the termites were dead within 4 days \\
\hline \multirow{3}{*}{$\begin{array}{l}\text { Clothianidin } \\
+ \text { Tween } 80\end{array}$} & $12.5+0$ & 26 & 3 & All the termites were dead within 3 days \\
\hline & $25+0$ & 18 & 2 & All the termites were dead within 3 days \\
\hline & $12.5+125$ & 24 & 3 & All the termites were dead within 3 days \\
\hline \multirow{3}{*}{$\begin{array}{l}\text { Imidacloprid } \\
+ \text { Tween } 80\end{array}$} & $25+0$ & 22 & 3 & All the termites were dead within 4 days \\
\hline & $37.5+0$ & 10 & 2 & All the termites were dead within 4 days \\
\hline & $25+125$ & 22 & 3 & All the termites were dead within 4 days \\
\hline \multirow{3}{*}{$\begin{array}{l}\text { Thiamethoxam } \\
+ \text { Tween } 80\end{array}$} & $50+0$ & 26 & 3 & All the termites were dead within 3 days \\
\hline & $100+0$ & 16 & 2 & All the termites were dead within 3 days \\
\hline & $50+250$ & 24 & 3 & All the termites were dead within 3 days \\
\hline
\end{tabular}

respectively (Table 1 ). No dead termites were found in the borings in the treated soil (Fig. 3). The water solubility levels of permethrin, bifenthrin, etofenprox and silafluofen were $0.2 \mathrm{ppm}\left(30^{\circ} \mathrm{C}\right),<0.1 \mathrm{ppb}\left(23^{\circ} \mathrm{C}\right), 0.02 \mathrm{ppm}$ $\left(20^{\circ} \mathrm{C}\right)$ and $0.001 \mathrm{ppm}\left(20^{\circ} \mathrm{C}\right)$, respectively. The treated soil layer contained $3 \mathrm{ml}$ of water. Therefore, the concentrations of the chemicals in the soil layer water were supposed to be lower than their minimum effective concentrations. Thus, the low water solubility pyrethroids were emulsified with the emulsifying agent, Tween 80 , which raised the termiticidal efficacy of the chemicals by about two fold of that of the corresponding chemical in the absence of the emulsifying agent. In addition, it took more than 11 days for the pyrethroids at the minimum effective concentrations to kill all the test termites in the tunneling tests of the chemicals (Table 1).

The minimum effective concentrations of the 4 neonicotinoids, dinotefuran, clothianidin, imidacloprid and thiamethoxam, required to fulfill the 
criteria of the JWPS-TS-S were 25 ppm (treatment conc.; 100 ppm), 25 ppm (100 ppm), $37.5 \mathrm{ppm}$ (150 ppm) and $100 \mathrm{ppm}$ (400 ppm), respectively (Table 2). No enhancement of the efficacy was obtained with the addition of Tween 80 to the neonicotinoids. The water solubility levels of dinotefuran, clothianidin, imidacloprid and thiamethoxam are $40,000 \mathrm{ppm}\left(20^{\circ} \mathrm{C}\right), 327$ ppm $\left(20^{\circ} \mathrm{C}\right), 510 \mathrm{ppm}\left(20^{\circ} \mathrm{C}\right)$ an $4,100 \mathrm{ppm}\left(25^{\circ} \mathrm{C}\right)$, respectively. Each of the chemicals was supposed as dissolving completely in the soil-layer water,

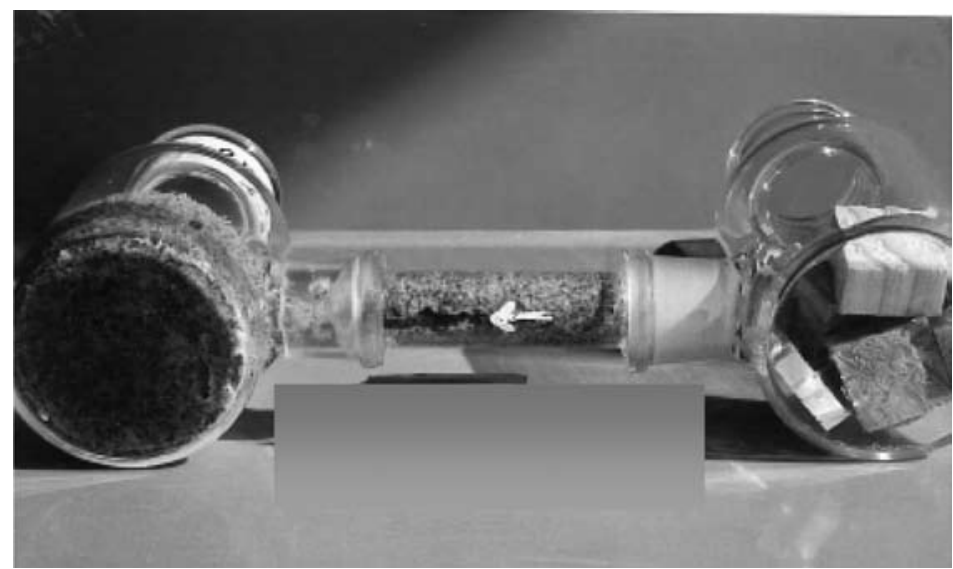

Fig. 3. Typical appearance of the soil in the tunneling test of a repellent rermiticide. No dead termites were found in the boring.

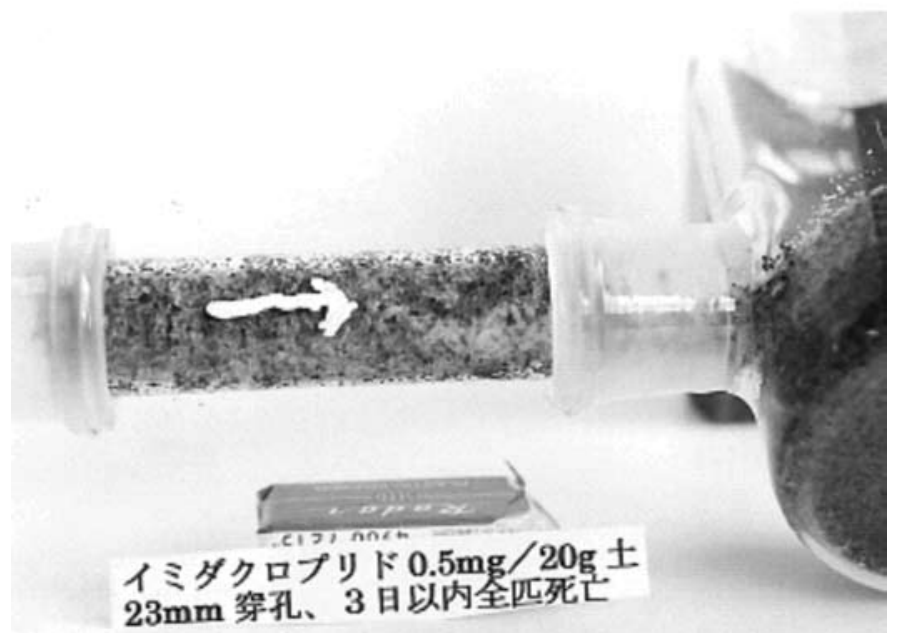

Fig. 4. Typical appearance of the soil in the tunneling test of a non-repellent termiticide. About 20 dead termites were found in the boring. 
Table 3. Termiticidal efficacy of fipronil, chlorfenapyr and chlorantraniliprole in the tunneling test. (JWPS-TS-S).

\begin{tabular}{|c|c|c|c|c|}
\hline Chemicals & $\begin{array}{l}\text { Conc. } \\
\text { in soil (ppm) }\end{array}$ & $\begin{array}{l}\text { Mean } \\
\text { boring } \\
\text { distance } \\
(\mathrm{mm})\end{array}$ & $\begin{array}{l}\text { Mean } \\
\text { boring } \\
\text { degree } \\
\text { (Avg.) }\end{array}$ & Notes \\
\hline \multirow{4}{*}{$\begin{array}{l}\text { Fipronil } \\
+ \text { Tween } 80\end{array}$} & $45+0$ & 31 & 4 & All the termites were dead within 2 days. \\
\hline & $75+0$ & 11 & 2 & All the termites were dead within 2 days. \\
\hline & $45+225$ & 22 & 3 & All the termites were dead within 2 days. \\
\hline & $45+450$ & 12 & 2 & All the termites were dead within 2 days. \\
\hline \multirow{6}{*}{$\begin{array}{l}\text { Chlorfenapyr } \\
+ \text { Tween } 80\end{array}$} & $250+0$ & 42 & 5 & All the termites were dead within 2 days. \\
\hline & $2,000+0$ & 19 & 2 & All the termites were dead within 2 days. \\
\hline & $250+250$ & 24 & 3 & All the termites were dead within 2 days. \\
\hline & $250+500$ & 20 & 3 & All the termites were dead within 2 days. \\
\hline & $250+750$ & 18 & 2 & All the termites were dead within 2 days. \\
\hline & $250+1,250$ & 4 & 1 & All the termites were dead within 2 days. \\
\hline \multirow{3}{*}{$\begin{array}{l}\text { Chlorantraniliprole } \\
+ \text { Tween } 80\end{array}$} & $125+0$ & 26 & 3 & All the termites were dead within 3 days \\
\hline & $250+0$ & 13 & 2 & All the termites were dead within 3 days \\
\hline & $125+500$ & 3 & 1 & All the termites were dead within 3 days \\
\hline
\end{tabular}

yielding concentrations higher than the minimum-effective concentrations. Thus, the addition of an emulsifying agent to such high water solublity chemicals, which dissolve completely in the water existing in the soil layer, exerts no influence on the efficacy of the chemicals. All the test termites were dead within 3 or 4 days. Several dead termites were usually found inside the borings in the treated soil layer (Fig. 4).

The minimum effective concentrations of fipronil, chlorfenapyr and chlorantraniliprole required to fulfill the criteria of the JWPS-TS-S were $75 \mathrm{ppm}$ (treated conc.; $300 \mathrm{ppm}$ ), 2,000 ppm (8,000 ppm) and $250 \mathrm{ppm}$ $(1,000 \mathrm{ppm})$, respectively (Table 3$)$. When Tween 80 was added to fipronil or chlorantraniliprole at 10 or 4 times the amount, the minimum effective concentrations of the chemicals decreased to $45 \mathrm{ppm}$ (treatment conc.: 180 $\mathrm{ppm})$ and $125 \mathrm{ppm}(500 \mathrm{ppm})$, respectively. In the presence of Tween 80 at 3 to 5 times concentration of chlorfenapyr, the minimum effective concentration of chlorfenapyr significantly decreased to $250 \mathrm{ppm}$ (1,000 ppm), one-eighth 
of that in the absence of Tween 80 . The water solubility levels of fipronil, chlorfenapyr and chlorantraniliprole are $2.4 \mathrm{ppm}\left(20^{\circ} \mathrm{C}\right), 0.12 \mathrm{ppm}\left(25^{\circ} \mathrm{C}\right)$ or $1 \mathrm{ppm}\left(20^{\circ} \mathrm{C}\right)$, respectively. Therefore, the concentration in the soil-layer water was supposed to be lower than its minimum effective concentration. Thus, the emulsification of low water solubility chemicals with Tween 80 raises their termiticidal efficacy.

All the test termites were dead within 2 or 3 days. Several dead termites were usually observed in the borings in the treated soil layer (Fig. 5).

\section{Confined test}

After ten worker and two soldier termites were introduced into the soil with $23 \%$ moisture content treated with each of the chemicals, the activities of the termites was assessed (Tables 4-6). The activities of all the test termites were maintained for more than 24 hours in the soil containing $625 \mathrm{ppm}$ or $1,250 \mathrm{ppm}$ of Tween 80 (Table 4). In the tunneling test, termites penetrated the soil layer containing 1,250 ppm of Tween 80 and reached the wood flakes within 5 to 6 hours (Table 1). Thus, the presence of Tween 80 at $1,250 \mathrm{ppm}$ in the soil had no efficacy on the termites. All the termites in the soils treated with the minimum effective concentrations of the 4 pyrethroids required to fulfill the criteria of the JWPS-TS-S in the tunneling tests were seriously intoxicated or paralyzed, stopped walking within one hour, and were dead

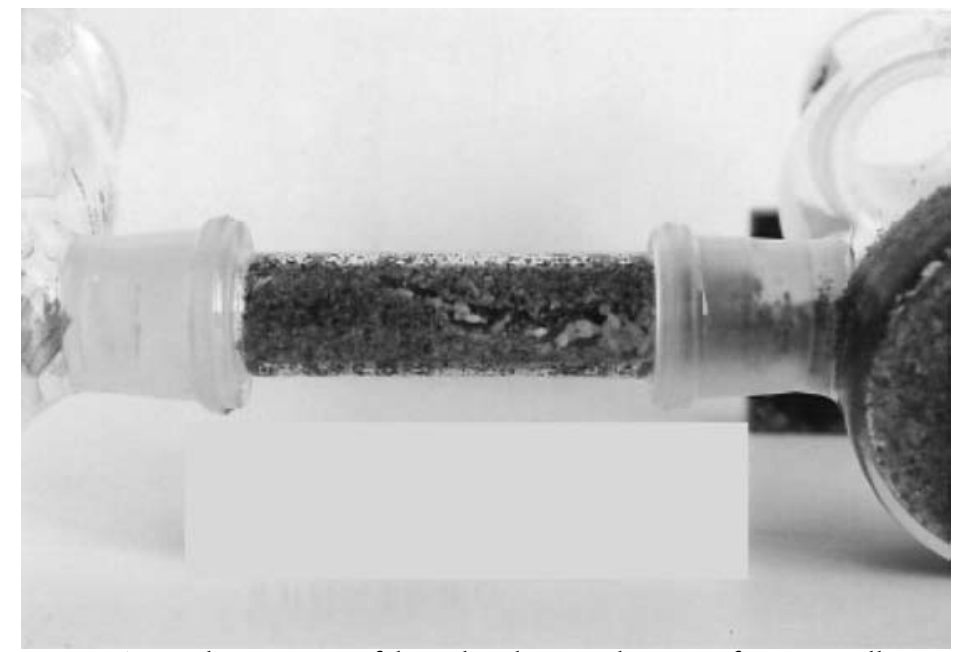

Fig. 5. Typical appearance of the soil in the tunneling test of a non-repellent termiticide. About 18 dead termites were found in the boring. 
Table 4. Time required for a $100 \%$ moribund or dead rate after treatment with the 4 pyrethroids, permthirin, bifenthrin, etofenprox, and silafluofen, in the confined test.

\begin{tabular}{|c|c|c|c|c|}
\hline \multirow{2}{*}{ Chemicals } & \multirow{2}{*}{$\begin{array}{l}\text { Conc. } \\
\text { in soil (ppm) }\end{array}$} & & \multicolumn{2}{|c|}{$\begin{array}{l}\text { Time required for } 100 \% \text { mori- } \\
\text { bund or dead rate (hr.) }\end{array}$} \\
\hline & & & Moribund & Dead \\
\hline \multirow{6}{*}{ Permethrin + Tween 80} & \multirow{2}{*}{$25+0$} & worker & 1 & 48 \\
\hline & & soldier & 1 & 24 \\
\hline & \multirow{2}{*}{$50+0$} & worker & 1 & 48 \\
\hline & & soldier & 1 & 24 \\
\hline & \multirow{2}{*}{$25+125$} & worker & 1 & 48 \\
\hline & & soldier & 1 & 24 \\
\hline \multirow{6}{*}{ Bifenthrin + Tween 80} & \multirow{2}{*}{$6.25+0$} & worker & 2 & 24 \\
\hline & & soldier & 2 & 24 \\
\hline & \multirow{2}{*}{$12.5+0$} & worker & 1 & 24 \\
\hline & & soldier & 1 & 24 \\
\hline & \multirow{2}{*}{$6.25+62.5$} & worker & 1 & 24 \\
\hline & & soldier & 1 & 24 \\
\hline \multirow{6}{*}{ Etofenprox + Tween 80} & \multirow{2}{*}{$100+0$} & worker & 1 & 48 \\
\hline & & soldier & 1 & 24 \\
\hline & \multirow{2}{*}{$200+0$} & worker & 1 & 48 \\
\hline & & soldier & 1 & 24 \\
\hline & \multirow{2}{*}{$100+500$} & worker & 1 & 48 \\
\hline & & soldier & 1 & 24 \\
\hline \multirow{6}{*}{ Silafluofen + Tween 80} & \multirow{2}{*}{$200+0$} & worker & 1 & 24 \\
\hline & & soldier & 1 & 24 \\
\hline & \multirow{2}{*}{$375+0$} & worker & 1 & 24 \\
\hline & & soldier & 1 & 24 \\
\hline & \multirow{2}{*}{$200+1,000$} & worker & 1 & 24 \\
\hline & & soldier & 1 & 24 \\
\hline \multirow{4}{*}{ Tween 80} & \multirow{2}{*}{625} & worker & $>24$ & - \\
\hline & & soldier & $>24$ & - \\
\hline & \multirow{2}{*}{1,250} & worker & $>24$ & - \\
\hline & & soldier & $>24$ & - \\
\hline \multirow{2}{*}{ Untreated } & \multirow{2}{*}{ - } & worker & $>24$ & - \\
\hline & & soldier & $>24$ & - \\
\hline
\end{tabular}


within one day or two days (Table 4). The time required for a $100 \%$ moribund rate of the worker termites was the same as that for the soldier termites. This indicates that these pyrethroids penetrate into the termite bodies through their skin, because the soldier termites of $C$. formosanus are unable to ingest materials orally by themselves. The time periods required for a $100 \%$ moribund rate of the test termites in soil containing $25 \mathrm{ppm}$ of permethrin, $6.25 \mathrm{ppm}$ of bifenthrin, $100 \mathrm{ppm}$ of etofenprox and $200 \mathrm{ppm}$ of silafluofen were only 1 hour, 1 hour, 2 hours and 1 hour, respectively, (Table 4) although none of the concentrations fulfilled the criteria for the tunneling test results (Table 1). The time period required for a $100 \%$ dead rate of the test termites in soil treated with the minimum effective concentrations of permetnrin, bifenthrin, etofenprox and silafluofen was 1 day or 2 days (Table 4), while that in the tunneling test was in the range of 11 to 17 days (Table 1). Furthermore, not even one dead termite usually existed in the borings excavated by the termites in the soils treated with the four pyrethroids (Fig 2). That is, all the termites were dead and observed outside the treated soils in the tunneling tests. These findings suggest that the four pyrethroids showed a high repellent efficacy against $C$. formosanus.

The time required for a $100 \%$ moribund rate of the worker termites in soil treated with the minimum effective concentrations of dinotefuran, clothianidin, imidaclroprid and thiamethoxam required to fulfill the criteria of the JWPS-TS-S for the tunneling test was 2 hours, while that of the soldiers was 5 hours, 6 hours, 6 hours and 7 hours, respectively (Table 5). Thus, the time required for the soldiers was 3 to 3.5 times that for the workers. These findings indicate that a large portion of the total amount of each chemical incorporated into the workers was ingested orally from the dissolved water in the soil in which the chemicals were completely dissolved. The time required for a $100 \%$ dead rate of the termites in the soil treated with the minimum effective concentration of each neonicotinoid required to fulfill the criteria of the JWPS-TS-S for the tunneling test was 1 day or 2 days (Table 5), while that in the soil containing the same concentration as that in the confined test was 3 or 4 days (Table 2). In the tunneling tests, several dead termites were usually observed in the borings excavated by the termites (Fig. 4 ). These findings indicate that these neonicotinoids had no repellent effect against the termites. Imidaclroprid has also been reported to be a non-repellent type of 
Table 5. Time required for a $100 \%$ moribund or dead rate after treatment with the 4 Neonicotinoids, dinotefuran, clothianidin, imidacloprid, and thiamethoxam, in the confined test.

\begin{tabular}{|c|c|c|c|c|}
\hline \multirow{2}{*}{ Chemicals } & \multirow{2}{*}{$\begin{array}{l}\text { Conc. } \\
\text { in soil }(\mathrm{ppm})\end{array}$} & & \multicolumn{2}{|c|}{$\begin{array}{c}\text { Time required for } 100 \% \text { mori- } \\
\text { bund or dead rate (hr.) }\end{array}$} \\
\hline & & & Moribund & Dead \\
\hline \multirow{6}{*}{ Dinotefuran + Tween 80} & \multirow{2}{*}{$12.5+0$} & worker & 3 & 48 \\
\hline & & soldier & 10 & 48 \\
\hline & \multirow{2}{*}{$25+0$} & worker & 2 & 48 \\
\hline & & soldier & 5 & 24 \\
\hline & \multirow{2}{*}{$12.5+125$} & worker & 3 & 48 \\
\hline & & soldier & 10 & 48 \\
\hline \multirow{6}{*}{ Clothianidin + Tween 80} & \multirow{2}{*}{$12.5+0$} & worker & 3 & 48 \\
\hline & & soldier & 6 & 24 \\
\hline & \multirow{2}{*}{$25+0$} & worker & 2 & 48 \\
\hline & & soldier & 6 & 24 \\
\hline & \multirow{2}{*}{$12.5+125$} & worker & 3 & 48 \\
\hline & & soldier & 6 & 24 \\
\hline \multirow{6}{*}{ Imidacloprid + Tween 80} & \multirow{2}{*}{$25+0$} & worker & 3 & 48 \\
\hline & & soldier & 8 & 48 \\
\hline & \multirow{2}{*}{$37.5+0$} & worker & 2 & 48 \\
\hline & & soldier & 6 & 48 \\
\hline & \multirow{2}{*}{$25+125$} & worker & 3 & 48 \\
\hline & & soldier & 8 & 48 \\
\hline \multirow{6}{*}{ Thiamethoxam + Tween 80} & \multirow{2}{*}{$50+0$} & worker & 3 & 48 \\
\hline & & soldier & 7 & 24 \\
\hline & \multirow{2}{*}{$100+0$} & worker & 2 & 24 \\
\hline & & soldier & 7 & 24 \\
\hline & \multirow{2}{*}{$50+250$} & worker & 3 & 48 \\
\hline & & soldier & 7 & 24 \\
\hline
\end{tabular}

termiticide (Ishizaka, 2004). The time required for a $100 \%$ moribund rate of the workers in soil containing $12.5 \mathrm{ppm}$ of dinotefuran, $12.5 \mathrm{ppm}$ of clothianidin, 25 ppm of imidaclroprid or 50 ppm of thiamethoxam was 3 hours. In the tunneling tests using the same concentrations of the neonicotinoids, the test termites dug a tunnel with a length of more than $20 \mathrm{~mm}$ in the treated soil, although all the test termites in the tunneling tests were dead within 4 days (Table 2). Termites seem to dig tunnels in untreated soil and to advance 
Table 6. Time required for a $100 \%$ moribund or dead rate after treatment with fipronil, chlorfenapyr and chlorantraniliprole in the confined test.

\begin{tabular}{|c|c|c|c|c|}
\hline \multirow{2}{*}{ Chemicals } & \multirow{2}{*}{$\begin{array}{l}\text { Conc. } \\
\text { in soil (ppm) }\end{array}$} & & \multicolumn{2}{|c|}{$\begin{array}{l}\text { Time required for } 100 \% \text { mori- } \\
\text { bund or dead rate (hr.) }\end{array}$} \\
\hline & & & Moribund & Dead \\
\hline \multirow{6}{*}{ Fipronil + Tween 80} & \multirow{2}{*}{$45+0$} & worker & 3 & 24 \\
\hline & & soldier & 5 & 24 \\
\hline & \multirow{2}{*}{$75+0$} & worker & 2 & 24 \\
\hline & & soldier & 4 & 24 \\
\hline & \multirow{2}{*}{$45+450$} & worker & 2 & 24 \\
\hline & & soldier & 4 & 24 \\
\hline \multirow{6}{*}{ Chlorfenapyr + Tween 80} & \multirow{2}{*}{$250+0$} & worker & 4 & 6 \\
\hline & & soldier & 7 & 8 \\
\hline & \multirow{2}{*}{$250+250$} & worker & 3 & 6 \\
\hline & & soldier & 6 & 7 \\
\hline & \multirow{2}{*}{$250+750$} & worker & 2 & 6 \\
\hline & & soldier & 4 & 7 \\
\hline \multirow{6}{*}{ Chlorantraniliprole + Tween 80} & \multirow{2}{*}{$125+0$} & worker & 3 & 72 \\
\hline & & soldier & 24 & 48 \\
\hline & \multirow{2}{*}{$250+0$} & worker & 2 & 72 \\
\hline & & soldier & 24 & 48 \\
\hline & \multirow{2}{*}{$125+500$} & worker & 2 & 72 \\
\hline & & soldier & 24 & 48 \\
\hline
\end{tabular}

by 8 to $10 \mathrm{~mm}$ per hour, because the termites penetrated the untreated soil layer over a length of about $5 \mathrm{~cm}$ and reached the wood flakes in the opposite cylinder within 5 to 6 hours (Table 1). These findings indicate that all the test workers were probably intoxicated or paralyzed within 2 hours in soil treated with the minimum effective concentration of a non-repellent type of chemical, required to meet the criteria of the JWPS-TS-S for the tunneling test.

The time required for a $100 \%$ moribund rate of the workers in soil treated with fipronil, chlorfenapyr and chlorantraniliprole at the minimum effective concentration required for fulfillment of the criteria of the JWPS-TS-S for the tunneling test was 2 hours (Table 6). This time period was the same as that for each of the neonicotinoids which exhibited no repellent effect against the termites. The value for the soldiers was 4 hours or 24 hours. The three chemicals were insoluble in water $(C a .4 .6 \mathrm{ml})$, existing in the soil in 
the confined tests. Emulsification of each of the chemicals with Tween 80 enhanced the termiticidal activity of each by 2 - to 8 -fold as compared with the efficacies in the absence of the emulsifying agent, as mentioned above (Table 3). These findings indicate that a large portion of the total amount of each chemical incorporated into the worker termites was ingested orally when the chemicals were emulsified. The time required for a $100 \%$ dead rate of the test termites in soil treated with fipronil, chlorfenapyr and chlorantraniliprole at the minimum treatment concentration required for fulfillment of the criteria of the JWPS-TS-S for the tunneling test was 1 day, 6 hours and 3 days, respectively (Table 6), while that in the tunneling test was 2 or 3 days (Table 3). Several dead termites usually existed in the borings excavated by the termites in the tunneling tests (Fig. 5). These findings indicate that the three chemicals had no repellent effect against the termites. Fipronil has also been reported as a non-repellent termiticide (Ibrahim et al., 2003).

The results of this study suggest that the water solubility of termiticides affects their termiticidal efficacy. Addition of an emulsifying agent improved the efficacy of the low water solubility chemicals, showing the possibility of the efficacy being improved depending on the formulation employed.

In another study at the field site in Kagoshima Prefecture, soil treatment with the emulsion of the chemicals $\left(3 \mathrm{l} / \mathrm{m}^{2}\right)$ at the minimum effective concentrations needed to fulfill the criteria of the JWPS-TS-S for the tunneling test could protect against termite attacks for at least 5 years.

\section{REFERENCES}

Enoki, A., K. Ueshima, S. Itakura, and H. Tanaka (1995) Termiticidal efficacy of organophosphates (II), Rate of disappearance of organophosphates in soil and wood. Mem. Foc. Agr. Kinki Univ. 28:1 - 9 (in Japanease).

Ibrahim, S. A., G. Henderson, and H. Fei (2003) Toxity, repellency, and horizontal transmission of fipronil in the Formosan subterranean termite (Isoptera: Rhinotermitidae). J. Econ. Entomol. 96: 461 - 467.

Ishizaka, K. (2004) New effective methods with a non-repellent termiticide, imidacloprid. Mokuzaihozone 30: 259 - 264 (in Japanease).

Kuriachan, I., and R.E. Gold (1998) Evaluation of the ability of Reticulitermesflavipes(Kollar), a subterranean termite (Isoptera: Rhinotermitidae) to differentiate between termiticide treated and untreated soils in laboratory tests. Sociobiology 32: $151-166$.

Schoknecht, U., D. Rudolf, and H. Hertel (1994) Termite control with microencapsulated permethrin. Pestc. Sci. 40: 49 - 55. 
Su, N. Y., V. Chew, G. S. Wheeler, and R. H. Scheffrahn (1997) Comparison of tunneling responses into insecticide-treated soil by field population and laboratory groups of subterranean termites (Isoptera: Rhinotermitidae). J. Econ. Entomol. 90: 503 - 509.

Tamashiro, M., J. R. Yates, and R. H. Ebesu (1987) The Formosan subterranean termite in Hawaii: problems and control, pp. 15 - 22 In M. Tamashiro and N-Y. Su [eds.], Biology and control of the Formosan subterranean termite. College of tropical Agriculture \&Human Resources, University of Hawaii, Honolulu. Ext. Series 083

Tsunoda, K. , T. Yoshimura, and K. Nishimoto (1989) Effect of accelerated ageing on the termiticidal performance of organophosphates (2). Soil burial. Material u. Organismen 24(1): $17-25$. 